(2) Open Access Full Text Article

\title{
Solitary synovial osteochondroma of the knee: mimicking a giant loose body
}

This article was published in the following Dove Press journal:

International Medical Case Reports Journal

31 October 2012

Number of times this article has been viewed

\author{
Nuri Aydin' \\ Kemal Gokkus ${ }^{2}$ \\ Cumhur Topal' \\ Ahmet Turan Aydin ${ }^{2}$ \\ 'Uskudar State Hospital, Istanbul, \\ Turkey; ${ }^{2}$ Memorial Antalya Hospital, \\ Antalya, Turkey
}

\begin{abstract}
Solitary synovial osteochondromas are rarely seen. Usually arising from the juxta-articular soft tissues without attaching to the bone, these lesions can be large and show clinical and radiological features of a malignant process. This report is about a 64-year-old woman with no history of trauma. She had a history of dull pain and a progressive limited range of motion that had been ongoing for 3 years. An unusual presentation of an uncommon disease that is not widely known by orthopedic surgeons is reported.
\end{abstract}

Keywords: solitary synovial osteochondroma, loose body, arthroscopy, knee joint, synovial chondromatosis

\section{Introduction}

Osteochondromas usually arise from the metaphyseal region of the growing skeleton, particularly around the knee and proximal femur. ${ }^{1}$ Solitary synovial osteochondromas are rarely seen. Usually arising from the juxta-articular soft tissues without attaching to the bone, these lesions can be large and show clinical and radiological features of a malignant process. ${ }^{2}$

This report is about a 64-year-old woman with no history of trauma. She had a history of dull pain and a progressive limited range of motion of the right knee that had been ongoing for 3 years. In this report, there is an unusual presentation of an uncommon disease that is not widely known by orthopedic surgeons.

\section{Case report}

A 64-year-old woman came to the authors' clinic with pain in the right knee and a limp. The pain had been going on for 3 years. There was no history of trauma. Physical examination revealed pain and tenderness in the lateral and medial joint lines. The range of motion was extremely limited in both flexion and extension planes. The plain radiograph and computed tomography scan showed unexpectedly large and bony (radiodense) structures as loose bodies (a main large one and two small ones) at the lateral compartment of the knee (Figure 1A and B). Magnetic resonance imaging showed that there were no irregularities or thickening of the cartilaginous cap greater than $1 \mathrm{~cm}$ (Figure 1C). Osteocartilaginous loose bodies were located on the adjacent lateral meniscus and joined with the lateral meniscus at the end. Surgical intervention was decided. Under general anesthesia with routine tourniquet application, initial diagnostic arthroscopy was performed and no chondral lesion or additional pathology that needed additional microfracture or antegrade drilling were detected. The lateral
Correspondence: Kemal Gokkus Private Memorial Antalya Hospital, Zafer Mah, Yildirim Beyazit Cad 91, Kepez, Antalya, Turkey

$\mathrm{Tel}+902423146666$

Fax +902423441678

Email kgokkus@yahoo.com 


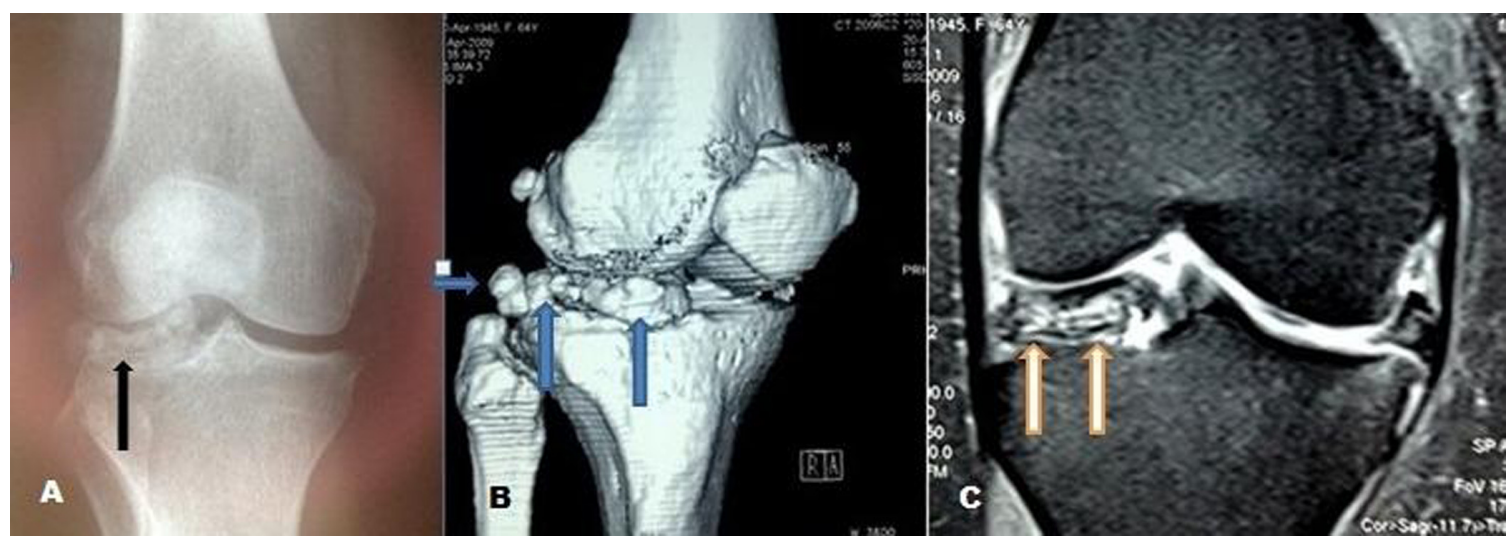

Figure I The (A) plain radiograph and (B) computed tomography scan shows unexpectedly large sized, bony structured (radiodense) loose bodies (black arrow and blue arrows) at the lateral compartment of the knee. (C) Magnetic resonance imaging examination shows osteocartilaginous structures (unusual large sized loose bodies, two small and one large) joining with the lateral meniscus.

Note: The lateral meniscus has lost its healthy appearance and has been overshadowed (orange arrows) by osteocartilaginous structures.

meniscus was crushed and almost destroyed due to a mass of large osteocartilaginous loose bodies. Initial arthroscopy was terminated and parapatellar lateral arthrotomy was performed. With this procedure, the large osteocartilaginous loose bodies were excised using lateral partial meniscectomy. The joint was washed with saline solution and cleaned from remaining parts of osteocartilaginous loose bodies. Following the excision, the visible joint pressure at the lateral compartment was reduced. The patient had a good postoperative period without complications and the knee pain resolved within 3 months following the operation. The patient was followed for 2 years without any recurrences.

Histopathological examination revealed the characteristic pattern of an osteochondroma which was covered by a thick cartilage cap with fibrous capsules next to fibrocartilaginous meniscus tissue. At the chondro-osseous junction, endochondral ossification, forming bony trabecula, was found (Figure 2).

\section{Discussion}

The most important finding of this study is realizing the fact that synovial osteochondromas can mimic a giant loose body of the knee.

There is no consensus in the literature about the nomenclature of this disease. The name of this disease changes from extraskeletal osteochondroma, extraskeletal cartilaginous tumor, and para-articular extraskeletal osteochondroma to solitary synovial osteochondroma. The term "solitary synovial osteochondroma" was used in this case because the lesion was adjacent to the lateral meniscus directly located in the joint, and therefore a suitable name for this anatomic location.
Synovial chondromatosis, Trevor's disease, or osteochondritis dissecans are classical causes of loose bodies, while the solitary synovial osteochondroma is not. Some cases of infrapatellar fat pads, posterior joint cavity or not protruding into the joint cavity as para-articular, replacing the anterior cruciate ligament at the intercondylar notch, and soft tissue, capsular, or ossifying chondroma have been reported. ${ }^{3-9}$

A search of the literature did not produce a previously published case of solitary synovial osteochondroma adjacent to the lateral meniscus directly located in the joint lateral compartment. An aim of this study was to emphasize the possibility of synovial osteochondroma during the differential diagnosis of osteocartilaginous loose bodies in the knee joint.

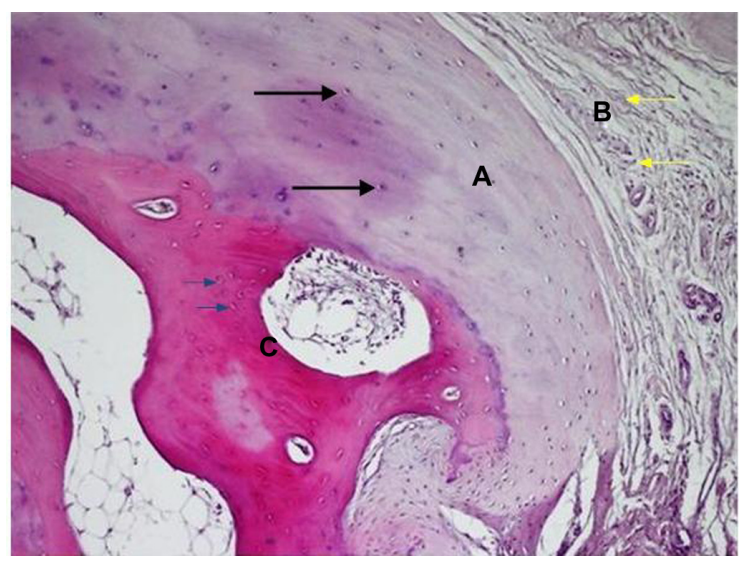

Figure 2 A histologic preparation of a synovial solitary osteochondroma $(\mathrm{H} \& \mathrm{E}, \times 10$ obj) revealed the characteristic pattern of an osteochondroma covered by a thick cartilaginous cap formed with columnar arrangement of chondrocytes typical for osteochondroma (black arrows [A]). The fibrous capsule was adjacent to the fibrocartilaginous meniscus tissue (yellow arrows [B]). At the chondro-osseous junction, an osteoid matrix with osteocytes forming bony trabecula is apparent at the base of the cap (blue arrows [C]). 
These type of tumors arise from the synovial cells themselves or the primitive cells lying within the synovium. ${ }^{10}$ These tumors are formed by metaplasia of the synovial cells to chondrocytes, giving rise to the islands of cartilage within the synovium, which can then lead to multiple loose bodies within the joint cavity with secondary mineralization. ${ }^{11}$

Some authors have argued that synovial osteochondroma is a variant of extraskeletal osteochondroma and others have said that synovial osteochondroma is a variant of synovial chondromatosis. ${ }^{7}$ Because of this, there is some controversy about this issue. However, in this case the hypothesis was more reasonable: some of the metaplastic foci or the synovial membrane surface can detach, creating a number of osteocartilaginous loose bodies. ${ }^{10,11}$ The synovial fluid feeds the loose bodies, which can remain alive and enlarge..$^{5,12,13}$

There are numerous cases reported in the literature about para-articular located synovial osteochondroma of the knee and a few cases of synovial osteochondroma located on the posterior joint cavity, anterior joint cavity behind the infrapatellar fat pads, and replacing the anterior cruciate ligament at the intercondylar notch. In the current case, the location was intra-articular and adjacent to the lateral meniscus. Histopathological examination revealed that the lesion was joined by meniscal fibrocartilage. Therefore, this case can be considered unique in the literature. The classical imaging appearance of synovial chondromatosis is multiple, oval-shaped, well-defined, intra-articular, and homogenous calcified bodies are typically distributed evenly through the joint. These calcifications frequently show a pathognomonic appearance similar to ring-and-popcorn (rice body) or feathery patterns of mineralization. ${ }^{14}$

In the current case, the osteocartilaginous loose body had a bigger size unlike oval-shaped rice bodies. The plain radiograph and computed tomography scan showed unexpectedly large sized and bony (radiodense) structures as loose bodies (a main large one and two small ones) at the lateral compartment of the knee (Figure 1A and B). At magnetic resonance imaging, there were no irregularities or thickening of the cartilaginous cap greater than $2 \mathrm{~cm}$ (Figure 1C). Histopathological examination revealed the characteristic pattern of an osteochondroma which was covered by a thick cartilage cap with fibrous capsules next to fibrocartilaginous meniscus tissue. At the chondro-osseous junction, endochondral ossification, forming bony trabecula, was found (Figure 2).

Trevor's disease, also known as dysplasia epiphysealis hemimelica, is a rare nonhereditary developmental skeletal disorder which affects epiphyses. It most commonly manifests in the medial half of the epiphysis of children and adolescents, with a male-to-female ratio of $3: 1 .^{15,16}$ This disease usually affects lower extremity joints, especially the ankle or knee. ${ }^{17}$ It can mimic synovial chondromatosis of the joints. ${ }^{18}$ In the current case, the age of the patient (64 years), certainly far from adolescence, helped to rule out the possibility of Trevor's disease.

Osteochondritis dissecans, posttraumatic osseous fragments, was ruled out by the anamnesis of the patient, which contained no evidence of previous injury. Additionally, magnetic resonance imaging and arthroscopic examination revealed no osteochondral defects at the tibial and femoral side.

\section{Conclusion}

In the current case, there were no irregular appearances and thickening of the cartilaginous cap was smaller than $1 \mathrm{~cm}$. Therefore, there was no evidence of malignancy. Synovial osteochondroma must be considered as a possibility in the cases of loose bodies in the knee joint.

\section{Disclosure}

The authors report no conflicts of interest in this work.

\section{References}

1. Greenspan A, Jundt G, Remagen W. Cartilage (chondrogenic) lesions In: Greenspan A, Jundt G, Remagen W, editors. Differential Diagnosis of Orthopaedic Oncology. 2nd ed. Philadelphia, PA: Lipincott Williams \& Wilkins; 2007:184-186.

2. Oliva F, Marconi A, Fratoni S, Maffulli N. Extra-osseous osteochondromalike soft tissue mass of the patello-femoral space. BMC Musculoskelet Disord. 2006; 7:57-63.

3. Reith JD, Bauer TW, Joyce MJ. Paraarticular osteochondroma of the knee: report of 2 cases and review of the literature. Clin Orthop Relat Res. 1997;334:225-232.

4. Kautz FG. Capsular osteoma of the knee joint. Report of four cases. Radiology. 1945;45(2):162-167.

5. Nikolaou VS, Giannakou N, Triantopoulou C, Pneumaticos S. Giant osteochondroma of the posterior cavity of the knee. Orthopedics. 2008; 31(11): 1142 .

6. Sakai H, Tamai K, Iwamoto A, Saotome K. Para-articular chondroma and osteochondroma of the infrapatellar fat pad: a report of three cases. Int Orthop. 1999;23(2):114-117.

7. Allahabadia VN, Kulkarni SS, Dogra AS, Bhosale PB. Solitary synovial osteochondroma of the knee. J Postgrad Med. 1995;41(4):113-114.

8. Kamal AF, Soendoro E, Hutagalung EU, Wiguna LA. Solitary synovial osteochondroma of the knee. Majalah Ketodkt Indones. 2009;59(5): 232-235.

9. Chung JW, Lee SH, Han SB, Hwang HJ, Lee DH. A synovial osteochondroma replacing the anterior cruciate ligament at the intercondylar notch. Orthopedics. 2011;34(2):136.

10. Fechner RE. Neoplasms and neoplasm-like lesions of the synovium. In: Ackermann LV, Spjut HJ, Abell MR, editors. Bones and Joints. Baltimore, MD: Williams \& Wilkins; 1976:157-162.

11. Minsinger WE, Balogh K, Millender LH. Tenosynovial osteochondroma of the hand. A case report and brief review. Clin Orthop Relat Res. $1985 ; 196: 248-252$. 
12. Sarmiento A, Elkins RW. Giant intra-articular osteochondroma of the knee. J Bone Joint Surg Am. 1975;57(4):560-561.

13. Leeson MC, Wilcox P, Greenberg B, Ewing JW. Giant intrarticular loose bodies of the knee. Cases demonstrate spectrum of the lesion. Orthop Rev. 1986;15(6):393-397.

14. Kang CH, Park JH, Lee DH, Kim CH, Park JM, Lee WS. Giant synovial chondromatosis of the knee mimicking a parosteal osteosarcoma: a case report. J Korean Bone Joint Tumor Soc. 2010;16(2):95-98.

15. Wynne-Davies R, Hall CM, Apley AG. Dysplasia epiphysealis hemimelica. In: Wynne-Davis R, Hall CM, Apley AG, editors. Atlas of Skeletal Dysplasias. New York, NY: Churchill Livingstone; 1985: 539-543.
16. Trevor D. Tarso-epiphyseal aclasis: a congenital error of epiphysial development. J Bone Joint Surg Br. 1950;32-B(2):204-213.

17. Fairbank TJ. Dysplasia epiphysealis hemimelica (tarso epiphyseal aclasis). J Bone Joint Surg Br. 1956;38-B(2):237-257.

18. Lin YH, Chou YJ, Yeh LR, Chen CK, Pan HB, Yang CF. Dysplasia epiphysealis hemimelica or Trevor's disease: a case report. Chin J Radiol. 2001;26(5):215-220.

\section{Publish your work in this journal}

The International Medical Case Reports Journal is an international, peer-reviewed open-access journal publishing original case reports from all medical specialties. Previously unpublished medical posters are also accepted relating to any area of clinical or preclinical science. Submissions should not normally exceed 2,000 words or
4 published pages including figures, diagrams and references. The manuscript management system is completely online and includes a very quick and fair peer-review system, which is all easy to use. Visit $\mathrm{http}: / /$ www.dovepress.com/testimonials.php to read real quotes from published authors.

Submit your manuscript here: http://www.dovepress.com/international-medical-case-reports-journal-journal 